\title{
XX. YÜZYIL BAȘLARINDA HINIS SANCAĞI'NIN İDARİ STATÜSÜ
}

Yakup KARATAŞ ${ }^{*}$

Mehmet Kerem KARASU**

\section{$\ddot{\mathrm{O}} \mathrm{z}$}

Günümüzde Erzurum'un bir ilçesi olan Hınıs, Osmanlı döneminde yine Erzurum'a bağlı yerleşim yerlerinden biriydi. Çeşitli dönemlerde kaza veya sancak olarak idare edilen Hınıs, Osmanlı reformlarından da etkilenerek idarede dönüşümler geçirmişti. 1871'den itibaren kaza olarak idare edilen bölge 1904'te çeşitli güvenlik sebepleriyle sancağa dönüştürülmüştü. $\mathrm{Bu}$ çalışmada sancak hâline getirilen Hınıs'ta ortaya konulan idari politikalar ve teşkilat çalışmaları ele alınmıştır. Yaklaşı 5 yıl sancak olarak yönetilen Hınıs'ın sosyal yapısı ve idarenin karşılaştı̆̆ çeşitli zorluklar ile bölgeye atanan mutasarrıfların profili de incelemeye tabi tutulmuştur. Osmanlı Arşivi'nin Dâhiliye kayıtlarının daha fazla dikkate alındığı bu çalışma Erzurum tarihine önemli bir katkı olarak da düşünülmektedir.

Anahtar Sözcükler: Erzurum Vilayeti, Hınıs, Osmanlı Taşra Teşkilatı, Așiretler, XX. Yüzy1l.

\section{ADMINISTRATIVE STATUS QUO OF SANJAK OF HINIS FOR EARLY XX ${ }^{\text {th }}$ CENTURY}

\begin{abstract}
Hinıs, as a district of Erzurum today, was one of settlement areas which related to Erzurum in the period Ottoman Empire. The district had effected from various reforms in terms of administration was ruled as a qaza or sanjak in varied periods. The region that had been ruled as a qaza by 1871 had been converted to sanjak because of some security reasons in 1904. Administrative policies and constructional efforts those exposed in Hinis after being converted to sanjak has handled in this study. Social structure, administrative difficulties and profiles of mutasarrifs of Hinıs where had been ruled as a sanjak approximately five years were also investigated. The study where the interior records of Ottoman Archive were mostly considered is evaluated as a remarkable contribution for history of Province of Erzurum.
\end{abstract}

Keywords: Province of Erzurum, Hinıs, Ottoman Provincial Governance, Tribes, $\mathrm{XX}^{\text {th }}$ Century.

\section{Giriş}

Bugün Erzurum’un güney ucunda yer alan Hınıs XIX. yüzyılın sonlarında Bingöl Dağ1 ve Tekman nahiyesini de içine alarak; güneyden Bitlis vilayeti, doğudan Bayezid Sancağı, kuzeyden Pasin, batıdan da Tercan ve Kiğı kazaları ile çevriliydi. ${ }^{1}$ Toplumsal yapının en önemli unsurunun aşiretler olduğu Hınıs'ta Osmanlı egemenliği kurulana dek oldukça sancılı süreçler yaşanmıştı. Zira aşağıda da görüleceği üzere XVI. yüzyılın başlarından itibaren Osmanlı, İran

\footnotetext{
*Yrd. Doç. Dr., Ağrı İbrahim Çeçen Üniversitesi Fen-Edebiyat Fakültesi Tarih Bölümü, yakup198025@ gmail.com.

** Arş. Gör.; Ağrı İbrahim Çeçen Üniversitesi Fen-Edebiyat Fakültesi Tarih Bölümü, mkeremk@ hotmail.com.

${ }^{1}$ Şemseddin Sami (1308/1893), Kâmûs-ül A 'lâm, İstanbul: Mihran Matbaası, C 3, s. 2061-2062.
} 
ve yerel hanedanlar arasında nüfuz mücadelelerinin yaşandığ bu bölge siyasi, idari ve demografik istikrarına Osmanlı idaresi altında kavuşmuştu.

Hınıs Akkoyunlular zamanından beri Malazgirt, Uçkan ve Muş ile birlikte Pazuki Aşireti beylerinin elinde olup bu devletin yıkılmasının ardından bölgedeki diğer aşiretlerle birlikte Pazuki Aşireti de Bitlis Emirliği’ne tabi olmuştu. Daha sonra Şah İsmail tarafından Pazuki Aşireti beyi Çolak Halid Bey’e verilen Hınıs, Halid Bey'in kendisine güvenmeyen Yavuz Sultan Selim tarafından öldürülmesi üzerine yine aynı sultan tarafından İskender ve Halil Selmi adındaki kişilerin idaresine bırakılmıştı. Osmanlı ordusunun Anadolu'ya hareket etmesi üzerine Bitlis civarındaki Şeref Bey ile Pazuki Aşireti, Hınıs'ın idarecilerini bölgeden çıkarmışlar ve Şah İsmail Hınıs’ı yeniden Pazuki Aşiretine vermişti. Böylece tekrar İran idaresine geçen Hınıs 1533 yılında Şah Tahmasb tarafından Şeref Han'ın idaresine bırakılmıştı. Hınıs, Veziriazam İbrahim Paşa'nın 1534'teki İran seferi sırasında yeniden Osmanlı egemenliğine girmişti. ${ }^{2}$ Şerefoğulları'nın idaresindeki Hınıs, 1537 tarihli tahrir defterine göre Diyarbekir Eyaleti'nin Bitlis Vilayeti’ne / Sancağına bağlı bir nahiyeydi. Hınıs 1543'den önce Bitlis’ten ayrılarak müstakil bir sancak olarak Erzurum Eyaleti'ne bağlanmıştı. Bu kaydı tespit eden tahrir defterine göre Hınıs; Handırıs (Handırıs+Varto), Bilican, Bulanık, Göksu, Elmalu ve Malazgird nahiyelerinden müteşekkildi. XVI. yüzyılın ortalarında İran saldırı ve yağmalarına uğrayan Hınıs'ta nüfusun da istikrarlı olmadığı tespit edilmiştir. ${ }^{3}$ Zira Erzurum Beylerbeyliğinin İran ile olan sınırı üzerinde bulunan Hınıs Sancağı 1548 ve 1552 yılları arasında iki defa İran kuvvetleri tarafindan yağma ve tahrip edilmiş bu yüzden 1556 tahririnde sancağa bağlı kimi köyler hali ve harap olarak kaydedilmişti. ${ }^{4}$

1555 tarihli Osmanlı - İran Antlaşmasından (Amasya Antlaşması) sonra demografik düzenin sağlandığı söylenebilir. Amasya Antlaşmasından sonra tutulan bir defterde ise Hınıs; Hınıs, Varto, Handırıs, Bulanık, Bilican, Suşehri, Göksu, Elmalu ve Malazgird olmak üzere toplam 9 nahiyeden müteşekkil bir sancak olarak kaydedilmişti. 1565'te Erzurum Eyaleti'ne bağlı olduğu anlaşılan Hınıs, Sultan II. Selim döneminde Hınıs, Varto, Handırı, Bulanık ve Bilican, Göksu, Malazgird, Elmalu ve Ayntab nahiyelerinden oluşmaktaydı. Aynı döneme ait

\footnotetext{
${ }^{2}$ Dündar Aydın (1998), Erzurum Beylerbeyliği ve Teşkilat- Kuruluş ve Genişleme Devri (1535-1566), Ankara: TTK Yayınları, s. 252.

${ }^{3}$ Hınıs Livası Mufassal Tahrir Defteri (2000), Yay. Haz. Ahmet Özkılınç, Ali Coşkun, Abdullah Sivridağ, Murat Yüzbaşığlu, Ankara: Devlet Arşivleri Genel Müdürlüğü Yayınları, s. 1-4.

${ }^{4}$ Aydın, Erzurum Beylerbeyliği, s. 253.
} 
bir başka defterde de sancak, Hınıs ve Tekman Livası olarak kaydedilmiştir. 1642 tarihli bir avarız defterine göre Hınıs, Bulanık ve Varto Nahiyelerinden oluşan bir kaza olarak verilmiştir. ${ }^{5}$

1568 - 74, 1578 - 88 ve 1632 - 41 tarihli tevcihat kayıtlarına göre Hınıs yine Erzurum Eyaleti'ne bağlı sancak olarak ifade edilmiştir. ${ }^{6} 1682$ - 1702 yılları arasında yine Erzurum Eyaleti'ne bağlı olarak Ocaklık suretiyle idare edilen Hınıs Sancağı, 1730 - 40 yıllarını ihtiva eden defterlerde de yine ocaklık sancak olarak gösterilmiştir. ${ }^{7} 1714$ tarihli bir icmal defterinde de sancak olarak kaydedilmiş ise de yurtluk - ocaklığ 1 belirtilmemiştir. ${ }^{8}$

1701 'den 1739 sonrasına kadar sırasıyla Hasan, Süleyman, Mustafa, Süleyman (ikinci defa) ve Şaban Beyler Hınıs mutasarrıfı olarak tayin edilmişlerdir.9

XVIII. yüzyılın sonlarına doğru yurtluk - ocaklık olarak idare edilmeye devam ettiği tespit edilen Hınıs ve Tekman Livaları bölgede daha etkin politika üretme çabasında olan Bayezid Mutasarrıfı II. İshak Paşa ile Hınıs ve Tekman Mutasarrıfı Veli Paşa arasındaki uzun süreli mücadelelerin temel konusunu teşkil etmişti. ${ }^{10}$ Erzurum Vilayeti'nin 1845 'te Tanzimat'a dâhil edildiği vakıasından hareketle Hınıs'ın yurtluk - ocaklık statüsünün bu tarihlerde kaldırıldığı ve toprakların mirice zapt edildiği hükmüne ulaşılabilir. ${ }^{11}$ Nihayetinde yeni vilayet nizamının tesis edildiği 1864 ve 1871 yıllarında Hınıs, Erzurum Sancağı'na bağlı bir kaza hâline getirilmiştir. ${ }^{12}$ Hınıs 1877 - 78 Osmanlı - Rus Savaşı öncesi ve sonrasında ve 1904 yılına kadar Erzurum Vilayeti'nin merkez sancağı olan Erzurum Sancağı'na bağlı bir kaza konumunu korumuştur. Bu konumunu 1904 yılına kadar muhafaza eden Hınıs, bu tarihte çeşitli güvenlik nedenleriyle sancağa dönüştürülmüş ve bu yeni statüde 1909 yılı ortalarına kadar idare

\footnotetext{
${ }^{5}$ Hınıs Livası Mufassal Tahrir Defteri, s. 5. Hınıs'ın sancak statüsüne ilk defa 1539'da kavuştuğu anlaşılmaktadır. İlk sancakbeyi de Ayna (İne) Hoca'dır. Aydın, Erzurum Beylerbeyliği s. 252.

6 İ. Metin Kunt (1978), Sancaktan Eyalete (1550-1650 Arasında Osmanlı Ümerası ve İl İdaresi), İstanbul, Boğaziçi Üni. Yayınları, s. 140, 174 ve 192.

${ }^{7}$ Orhan Kılıç (1997), 18. Yüzyılın Illk Yarısında Osmanlı Devleti'nin İdari Taksimatı-Eyalet ve Sancak Tevcihatı, Elazı̆g, s. 64.

${ }^{8}$ Hınıs Livası Mufassal Tahrir Defteri, s. 5. 1673-1740 yılları arası idari teşkilatı ele alan bir çalışmaya göre Erzurum Eyaletine bağlı yurtluk-ocaklık sancaklar şunlardır: Pasin, Hınıs, Malazgird, Micingerd, Kuzucan, Kiğı, Bayezid Kalesi, Eleşkirt, Köy, Şelve ve Diyadin Sancakları. Orhan Kılıç, "Ocaklık Sancakların Osmanlı Hukukunda ve İdarî Tatbikattaki Yeri”, http://web.firat.edu.tr/sosyalbil/dergi/arsiv/cilt11/sayi1/257-274.pdf.

${ }^{9}$ Kılıç, Eyalet ve Sancak Tevcihatı, s. 169-170. Bir başka kayıtta 1720'lerden itibaren Hınıs'a mutasarrıf olarak atanan Ömer ve İbrahim Beylerden de bahsedilmektedir. Fahameddin Başar (1997), Osmanlı Eyalet Tevcihatı (17171730), Ankara: TTK Yayınları, s. 115-116.

${ }^{10}$ Yakup Karataş (2014), Bayezid Sancağ ve İdarecileri (1700-1914), s. 30-34.

${ }^{11}$ Karataş, Bayezid Sancă̆ $\mathrm{v}$ ve İdarecileri, s. 116.

${ }^{12}$ Hinıs Livası Mufassal Tahrir Defteri, s. 5.
} 
edilmiştir. ${ }^{13}$ Bu çalışmada Hınıs'ın XX. yüzyılın başlarında kazadan sancağa dönüştürülme süreci ve bu sürecin iç dinamikleri incelemeye tabi tutulmuştur.

\section{Yüzyılın Başlarında Hınıs}

XX. yüzyılın başlarındaki (1907 yılına ait) Osmanlı coğrafyasını tanıtan bir kaynağa göre Hınıs, Erzurum Vilayeti’nin bir sancağıdır. Aynı kaynağa göre 3. sınıf bir sancak olan Hınıs; Hınıs, Madrak, Hacı Halil, Söylemez ve Karaçoban nahiyelerinden müteşekkildir. Bu teşkilatta sancak hâlinde olan Hınıs'a herhangi bir kazanın bağlanmadığı anlaşılmaktadır. ${ }^{14}$ Zaten 1908 tarihli bir kayıtta da Hınıs'a bağlı kaza bulunmadığı ve nahiyelerin tüm işlemlerinin sancak merkezinden idare edildiği belirtilmiştir. ${ }^{15}$

Hınıs 1315 / 1900 yılına ait vilayet salnamesine göre Erzurum'un güneybatısında 204 köyü ihtiva eden oldukça geniş ve mevkii ehemmiyeti olan bir kazadır. Kasabada yüksekçe bir kaya üzerinde kare planlı olarak inşa edilmiş bir kale ve bu kalenin etrafını çevirmiş ilginç görünümlü surları vardır. Söz konusu tarihlerde kasabada 13 cami ve mescit, 3 tekye, 20 kilise ve manastır, birer rüştiye ve iptidaiye mektebi, 99 medrese, 1 hükümet konağ 1,1 asker kışlası, 1 telgraf-hane, 30 dükkân ve mağaza, 3 firın, 4 meyhane, 1 han, 29 bezirhane, 1 boyahane, 119 değirmen, 179 çeşme, 4 köprü, 1015 arsa, 122 yaylak ve 220 kabristan vardır. Arpa, buğday, çavdar, darı, zegrek, nohut, mercimek, kavun ve karpuz gibi ürünler yetiştirilmektedir. Kasaba kadınları evlerinde seccade, kilim, şal, iyi kalite tiftik eldiven, çorap ve tozluk yaparlar. Çeşitli sanat kolları olarak da demirci, nalbant, bakırcı, kalaycı, taşçı ve dülger gibi sınıflar mevcuttur. ${ }^{16}$ Kâmûs-ül A'lâm'da, Hınıs'ta 1892 - 93 yılları itibariyle mevcut 26 mektep ve 35 medreseden bahsedilmektedir. Cuinet de aynı yıllara ait olarak 1 Rüştiye ve 25 iptidai mektebin mevcut olduğunu bildirmiş, medrese sayısını vermemiştir. ${ }^{17}$ Böylece yerli ve yabancı kaynakların söz konusu dönemde Hınıs’taki eğitim kurumları hususunda hemfikir olduğunu ifade etmek mümkündür.

Hınıs'ın nüfusu ile ilgili yine yerli ve yabancı kaynaklar arasında bir tutarlılık olduğu söylenebilir. 1892 yılına ait verileri ihtiva eden Cuinet'in seyahatnamesine göre bu tarihte

\footnotetext{
${ }^{13}$ Yakup Karataş, (2010), Sultan II. Abdülhamid Dönemi'nde Erzurum (Sosyal, Ekonomik, İdarî ve Demografik Yapı), (Yayımlanmamış Doktora Tezi) Atatürk Üniversitesi Sosyal Bilimler Enstitüsü, Erzurum, s. 31-32.

${ }^{14}$ Binbaşı M. Nasrullah, Kolağası M. Rüşdü, Mülazım M. Eşref (2003), Osmanlı Atlası (XX. Yüzyıl Başları), (Yay. Haz. Rahmi Tekin, Yaşar Baş), İstanbul: OSAV Yayınları, s. 75.

${ }^{15}$ Başbakanlık Osmanlı Arşivi, Dâhiliye Tesri-i Muamelat ve Islahat Komisyonu, Islahat Kısmı (BOA. DH. TMIK. S) Dosya Numaras1: 72, Gömlek Numaras1: 30.

${ }^{16}$ Salname-i Vilayet-i Erzurum (SVE) 1315/1900, Erzurum, s. 222-223.

${ }^{17}$ Ş. Sami, Kâmûs-ül A'lâm, 2062. Vital Cuinet, La Turquie d'Asie, Geographie, Administrative, Statistique, Descriptive et Raisonnee de Chaque Province de L'asie Mineure, Paris 1892, c.I. s 201.
} 
Hınıs’ta; 16.746 Müslüman, 9.312 Gregoryen Ermeni, 761 Protestan Ermeni ve 148 de diğer milletlerden olmak üzere toplam 26.967 kişi bulunmaktadır. ${ }^{18}$ Erzurum vilayet salnamesine göre 1900 yılında Erzurum vilayetinin toplam nüfusu 647.010 kişi iken Hınıs'ın toplam nüfusu 27.439'dur. Buradaki kayıtlardan yola çıkarak Hınıs'ın nüfusunun vilayetin toplam nüfusuna oranının yaklaşık \%4,3 civarında olduğu söylenebilir. Salnameye göre Hınıs’ta toplam 18.603 Müslüman, 8.506 Ermeni ve 330 adet de diğer milletlerden nüfus bulunmaktadır. ${ }^{19}$ Dolayısıyla 1892 - 1900 yılları arasında nüfusta çok önemli bir değişiklik olmadığı anlaşılmaktadır. Buna göre Müslüman nüfus gayrimüslim nüfusun yaklaşık iki katı civarındadır.

XX. yüzyılın ilk yıllarında Hınıs'taki en önemli meselelerin, bir takım aşiretlerin uygunsuzlukları ile Ermeni çetelerinin zararlı faaliyetleri olduğu anlaşılmaktadır. Erzurum Valisi Mustafa Nazım Paşa'nın 10 Şubat 1904 tarihli bir dilekçesinde Hınıs'ın stratejik öneminin günden güne artmakta olduğundan bahsedilerek Malazgirt tarafindan gelen bazı Kürt aşiretlerinin yağmaladıkları malları Bitlis'e aşırdıkları, bazı Ermenileri öldüren canilerin de keza o tarafa kaçtıkları bildirilmiștir. Diğer taraftan Sason'a yakın olan Hınıs'ta Ermeni propagandasının arttığı da ifade edilerek Sason olayında Hınıs Ermenilerinin de hadiseye müdahale etmeye niyetlendikleri belirtilmiştir. Tüm bu olumsuzlukların önünü alabilmek için de hâlen kaza hâlinde olan Hınıs'ın sancak statüsüne kavuşturulmasını teklif eden vali, 4. Ordu Müşirliğinin de bu konuda hemfikir olduğunu bildirmiştir. Valinin mütalaasına göre bu suretle hem dâhili emniyet ve asayiş temin edilecek hem de Ermenilerin ihtilalci girişimleri akim bırakılacaktır. ${ }^{20}$ Erzurum valisinin bu mütalaa ve teklifinin merkezi hükümetçe müspet olarak karşılandığı anlaşılmaktadır. Zira 22 Şubat 1904 tarihli bir Başkitabet evrakında Bitlis’teki Ermeni olayları üzerine bir takım talimatlardan sonra Hınıs'ın sancağa dönüştürülmesine dair padişah iradesinin çıktığı belirtilmiştir. ${ }^{21}$ Görüldüğü üzere uzun bir süre kaza hâlinde kalan Hınıs, çeşitli güvenlik nedenleriyle 1904 yılında sancak hâline getirilmiştir.

Hınıs’ta sosyal yapı önemli ölçüde aşiretlerden oluşmaktaydı. Bu yapıyı kazanın sosyokültürel formasyonunu oluşturan temel faktör olarak görmek mümkündür. Sultan II. Abdülhamid'in aşiretleri alaylara dönüştürme projesi kapsamında ihdas edilen Hamidiye Hafif

\footnotetext{
${ }^{18}$ Cuinet, La Turquie d'Asie, c.I. s. 200.

${ }^{19}$ SVE, s. 320-321.

${ }^{20}$ BOA. Ylldı Mütenevvi Maruzat (Y. MTV.), 255/221. 1890'lardan itibaren Erzurum'da ortaya çıkan Ermeni propagandist ve teröristleri vilayetin genelinde olduğu gibi Hınıs'ta da olaylar çıkmasına yol açmıştı. 1895'teki Hınıs olayı bölgedeki mülki ve askerî yetkililerle Anadolu Müfettişi Şakir Paşa'nın gayretleri sonucunda kısa sürede bastırılmıştı. Ali Karaca (1993), Anadolu Islahatı ve Ahmed Şakir Paşa (1838-1899), İstanbul: Eren Yayınları, s. 69.

${ }^{21}$ BOA. Yıldız Perakende Başkitabet Evrakı (Y. PRK. BŞK), 71/97. Bir başka kayıtta Hınıs'ın 3. Sınıf Sancak statüsüne haiz olduğu belirtilmiştir. BOA. Dâhiliye Mektubi Kalemi Evrakı (DH. MKT). 891/26.
} 
$680^{*}$ TAED 54

Yakup KARATAŞ, Mehmet Kerem KARASU

Süvari Alaylarına Hınıs'taki kimi aşiretler de dâhil olmuştur. İlk teşkilat döneminde bölgedeki Zırikî Aşiretinden iki alay teşkil edilmiş; bu alayların görev alanı da Hınıs, Tekman, Göksu ve Hacı Ömer dolayları olarak belirlenmişti. 1896'daki düzenlemeden sonra İkinci Liva olarak teşkil edilen Hınıs alayları; Camedanlı Aşireti (8. Alay), Cibranlı Aşireti (31, 32, 33 ve 36. Alaylar) ve Zırkanlı Aşireti'nden (34 ve 35. Alaylar) meydana getirilmiştir. 1899 tarihli teşkilatta bölgedeki Hasenanlı Aşiretinin de alaylara dâhil edildiği anlaşılmıştır. Hamidiye Alayları 1909 yılında Aşiret Hafif Süvari Alaylarına dönüştürülünce Hınıs’taki aşiret alayları III. Ordu’ya bağlı I. Aşiret Tümeni içerisinde yer bulmuştur. Aşiret alayları 1913 yılında İhtiyat Süvari Alayları adı altında yeniden teşkilatlandırılmıştır Buna göre IX. Kolordu'ya mensup, merkezi Erzurum olan Birinci Süvari Fırkası'nın 1, 2, 3, 4 ve 25. Alayları Hınıs'taki aşiretlerden müteşekkildir. ${ }^{22}$

Hınıs’taki sosyal yapısının önemli bir unsuru olan aşiretler her ne kadar alaylarda güzel askeri hizmetlerde bulunmuşlar ise de alay mensubu aşiretlerin yer yer uygunsuzlukları da vaki olmuştur. Bu hükmü teyit eden 1901 tarihli bir kayıtta Cibranlı, Hasenanlı ve daha başka aşiretlerin Hınıs'ın Çay Nahiyesindeki çoğu Müslüman olan ahaliye çeşitli zulümler yaptıklarından bahsedilerek bunlara güç yetiremeyen halkın göçe mecbur olduğu vurgulanmıştır. Dâhiliye Nezareti'nden Erzurum valiliğine gönderilen telgrafla tahkikatın yapılarak lüzumlu tedbirlerin alınması istenmiştir. ${ }^{23} 1907$ yılına ait bir örnekte ise 34. Alay Kaymakamı Selim Bey ile aynı alayın Binbaşısı Hasan Efendi, kendi aralarındaki geçimsizlikten dolayı birbirlerinin köylerini basıp türlü mezalimde bulunmuşlardır. Neticede, devletin silahını taşıyıp sıfat ve rütbelerini kullanan bu gibi kimselerin zalimane hareketlerinin tasvip edilmesinin mümkün olmadığı belirtilerek Erzurum'daki mülki ve askerî yetkililerden bunların itaat ve intizam altına aldırılmaları istenmiştir. ${ }^{24} 1908$ yılında ise Zıriki Aşireti'nin Ermeni ahalinin meskûn olduğu Yahya Karyesi’ne yönelik saldırıları ve ahaliye uygulanan zulümler dile getirilmiştir. Adliye ve Dâhiliye Nezaretleri gerekenin yapılması için Erzurum Vilayeti'ne telgraf göndermiştir. ${ }^{25} \mathrm{Bu}$ örneklerden görüldüğü üzere aşiretler, Hınıs kaza hâlinde iken de sancak hâlinde iken de çeşitli usulsüz ve yolsuz hareketlerde bulunarak bölgenin ve ahalinin emniyet ve asayişini ihlal eden durumlara sebep olmuşlardır.

\footnotetext{
22 Selçuk Günay, "Hamidiye Hafif Süvari Alayları ve Erzurum”, Türk Dünyası Araştırmaları Dergisi, Nisan 1988, S. 53 , s. $82-84$.

${ }^{23} B O A, D H . M K T, 2482 / 94$. Bilindiği üzere alayların oluşturulmasının temelinde muhtemel bir Rus istilası veya Ermeni çetelerinin saldırılarına karşı savunma hattı oluşturmak görüşü bulunmaktadır.

${ }^{24}$ BOA. Babıali Evrak Odasi Belgeleri (BEO). 3057/229235.

${ }^{25}$ BOA. DH. MKT. 2624/97.
} 
1908 yılında Hınıs Mutasarrıfı Ahmed Macid Bey’in sancaktaki jandarma teşkilatının takviye edilmesi ile ilgili bir arizasında bölge hakkında önemli bilgiler sunulmuştur. ${ }^{26}$ Buna göre nüfusu sürekli artan Hınıs, 250'den fazla köy ve pek çok köm ve mezradan oluşan idari yapısıyla Erzurum vilayetinin belki en karışık yerlerinden biridir. Bunun yanında ahalisi tek tip olmayıp Türk, Kürt, Çerkes ve Ermeni gibi çeşitli unsurlardan oluşmaktadır. Aşiretler nüfus olarak esaslı bir yekûn oluşturmaktadır. Bölgedeki aşiretler kendi reis ve ağalarına tabi olduklarından nahiye müdürleri hükümetin emirlerini icrada yetersiz kalmaktadırlar. Hınıs, vergilerin düzenli toplanamadığı; asker kaçaklarının önünün alınamadığı; yağma, gasp, cinayet ve yaralama gibi suçların engellenemediği; postaların güvenle sevk edilemediği ve gerekli 1slahatın yapılamadığı bir yerdir. Böyle bir yerde jandarma teşkilatının on beş sene önceki mevcuduyla kalmasının söz konusu sorunların giderilmesine imkân vermeyeceği ortadadır. Bu ifadelerden sonra mevcut kolluk kuvvetlerinin artırılması talebinde bulunan mutasarrıf, ayn mealdeki dilekçesini Dâhiliye Nezaretine de sunmuştur.

Hınıs'taki kimi aşiret reisleri Hamidiye Alay komutanı olsalar dahi vergi tahsilatı konusunda bir takım yolsuzluklara yol açarak hazinenin zarar görmesine de sebep olmuşlardır. Zira 1908 yılına ait bir kayıtta Hamidiye 29. Alay Kaymakamı Taceddin Bey'in toplanan vergiyi zayi ettiği, bazı köylerde de aşiret reislerinin korkusundan vergi iltizamı için kimsenin talip olmadığ Hınıs'ta aşiretlere bağlı köylerin vergisinin askeriye tarafından emaneten idare edilmesi kararı alınmışt1. ${ }^{27}$

\section{Hınıs Mutasarrıfları}

Osmanlı vilayet nizamında sancaklardaki en büyük mülki amir Mutasarrıf idi. Sancakbeyleri klasik dönemden beri mutasarrıf olarak ifade edilirken Tanzimat reformları ile birlikte aynı makamı ifade etmek için Kaymakam unvanı kullanılmaya başlamıştı. 1871 yılındaki yeni vilayet nizamı da sancak yöneticileri için eskiden olduğu gibi yine Mutasarrıf unvanının kullanılmasını öngörmekteydi. ${ }^{28}$ Dolayısıyla aşağıda da görüleceği üzere sancak statüsünü haiz olduktan sonra Hınıs'a atanan mülki amirler için keza Mutasarrıf unvanı kullanılacaktır.

\footnotetext{
${ }^{26}$ BOA. DH. TMIK. S. 72/30.

${ }^{27}$ BOA. BEO. 3438/257787.

${ }^{28}$ Karataş, Bayezid Sancă̆l ve İdarecileri, s. 7.
} 
Hınıs'ın kazadan sancağa dönüştürülmesinde önemli katkıs1 olan 4. Ordu Müşiri Mehmed Zeki Paşa, 22 Şubat'ta kaleme aldığı bir yazıda kardeşi Dersim eski Mutasarrıfı Ahmed Paşa'nın yeni açılan Hınıs Mutasarrıflığına tayinini istemiştir. Zeki Paşa bu istekte, kardeşinin, hem Kürtlerin hem de Ermenilerin mizaç ve tabiatlarına olan vukufiyetine dikkat çekerek gayet güzel hizmetlerde bulunacağını ümit ettiğini dile getirmiştir. ${ }^{29}$ Zeki Paşa'nın merkezi hükümet ve bilhassa Saray nezdindeki tesir ve nüfuzuna rağmen kardeşi Ahmed Paşa'dan sarfı nazarla Bitlis Vilayeti mektupçuluğunda görevli Tahir Efendi Hınıs Mutasarrıfı olarak atanmıştır. Tahir Efendi'nin ataması ile ilgili padişah iradesinin tarihi 14 Mart 1904'tür. $\mathrm{Bu}$ atamanın finansmanı için de lağvedilen Cezayir-i Bahr-i Sefid Vali Muavinliği maaşı kullanılmıştır. Şöyle ki vali muavinliği maaşı olan 4.500 guruşun 3.500 guruşu Hınıs mutasarrıflığı maaşına tahsis edilmiştir. ${ }^{30}$ Tahir Efendi 1906 yılının Mayıs ayına kadar Hınıs mutasarrıflığında bulunmuştur. Bu tarihlerde yerine Bayburt Kaymakamı Ali Nevzad Bey'in atandığı anlaşılmaktadır. Tahir Bey’in görevden alınmasıyla ilgili yazışmalardan anlaşıldığ kadarıyla sancaktaki tahrirat müdürü ve muhasebeci ile yaşadığı kişisel sorunlar ve idarede gösterdiği zafiyet azlinin temel sebeplerini oluşturmuştur. Öte yandan bu tür uygunsuzluklar vergi tahsilatı ve koyun sayımı gibi hazineyi ilgilendiren mali işleri de aksattığı ve hazine zarar gördüğü için adı geçenlerin görevden alınarak yerlerine yenilerinin atanması uygun bulunmuştur. Hınıs'ın Müslüman ve Hristiyan ahalisi de bu yolsuzluklardan şikâyetçi olmuştur. Erzurum valiliğince görevlendirilen iki müfettiş olayları tahkik ederek Tahir Efendi’nin sancak teşkilatındaki zaafları ve askerî ve mülki memurlar arasına soğukluk sokması gibi olumsuzlukları üzerinde durmuştur. Bu belge koleksiyonu arasında yer alan, dönemin Erzurum Valisi Ata Bey’in mazbatasında Hınıs'a azledilmiş mutasarrıfların pek rağbet etmediği, mecburen, kaymakamlıktan yükselmek isteyenlerin buraya atanması gerektiği ifade edilmiştir. Netice itibariyle Nevzad Bey’in Hınıs Mutasarrıfı olarak atandığı ve göreve başlama tarihinden itibaren kendisine 3.500 guruş maaş verileceği belirtilmiştir. ${ }^{31} \mathrm{Bu}$ durumda Tahir Efendi’nin Hınıs'taki en önemli eserlerinin aşağıda da görüleceği üzere sancağa bir hükümet konağının kazandırılması ve sancak teşkilatına dair ilk teşebbüslerin gerçekleştirilmesi olduğu anlaşılır.

\footnotetext{
${ }^{29}$ BOA. Ylldiz Perakende Askeri Evrakı (Y. PRK. ASK) 213/33.

${ }^{30}$ BOA. BEO, 2294/172019.

${ }^{31}$ BOA. DH. MKT. 1104/13. Mutasarrıf Tahir Efendi ve Tahrirat müdürünün yekdiğeri aleyhindeki ihbar ve ithamlarına bakılırsa; Tahir Efendi Bitlis’te iken siyasete bulaşmış ve bu yüzden görevden alınmıştır. Tahrirat müdürü ise 1906-1907 Erzurum Olayları sırasında Hınıs halkını galeyana getirmek gibi suçlara karışmıştır. BOA. DH. MKT. 1128/75. Mutasarrıf ve tahrirat müdürünün bir biri aleyhindeki ihbarları görevlerinden alındıktan sonra da devam etmiştir. BOA. Zabtiyye Nezareti Belgeleri (ZB), 318/101.
} 
Nevzad Bey'in atanmasıyla ilgili nihai hüküm olan padişah iradesi 19 Haziran 1906 tarihinde tahakkuk etmiştir. ${ }^{32}$

1907 yılı Haziranına kadar mutasarrıflık görevinde kalan ve Malatya Mutasarrıflığına atanan ${ }^{33}$ Nevzad Bey'in yerine, anılan tarihte Ahmed Macid Bey atanmıştır. Aydın Vilayeti Umur-1 Ecnebiye eski müdürü olan Macid Bey'in göreve başlama tarihinden itibaren kendisine 3.500 guruş maaş bağlandığı da bildirilmiştir. ${ }^{34}$ Macid Bey'e aynı tarihte Birinci Rütbeden Mecidi Nişanı verilmiştir. ${ }^{35}$ Macid Bey 1908 yılı ortalarında yeni teşkil olunan Siverek Mutasarrıflığına atanmış, Onun yerine Hınıs'a da Cebel-i Rime eski kaymakamı Halil Şahab Bey yine 3.500 guruş maaşla tayin edilmiştir. ${ }^{36} \mathrm{Bu}$ tayin de keza Haziran ayında gerçekleşmiştir. Macid Bey'in Siverek gibi yeni teşkil edilen bir sancağa atanması, onun Hınıs’taki sancak teşkilatında gösterdiği gayretlerin bir neticesi olarak değerlendirilebilir. Halil Şahab Bey'in Hınıs'taki vazifesinin uzun sürmemiştir. Zira 1908 yılı Kasım ayına ait bir kayıtta -isim verilmeyerek- Hınıs mutasarrıfının azledildiği ve yerine Nevşehir Kazası kaymakamı Ahmed Rami Bey'in atandığı belirtilmiştir. Bu atamada da yine maaşı düşük olduğu için Üçüncü dereceden bir sancak olan Hınıs'a mazûl mutasarrıfların rağbet etmediği, Birinci Sınıf kaymakamlıktan yükselmeye hak kazanan ve sicili temiz (ilişiği bulunmayan) kaymakamlardan birinin atandığı belirtilmişti. ${ }^{37} \mathrm{Bu}$ atamanın iradesi aynı yılın Aralık ayında çıkmışt. ${ }^{38}$

Ahmed Rami Bey'in daha Hınıs'ta göreve başlamadan yapılan bir değişiklikle Hınıs'a bu sefer Loris Kaymakamı Ali Ulvi Bey 3.500 guruş maaşla atanmıştır (Ocak-1909). Rami Bey'in görevden alınma sebebi açıklanmamış, sadece "görülen lüzum üzerine” şeklinde bir kayıt düşülmüştür. ${ }^{39}$ Sancak teşkilatı henüz tamamlanmadan ve kadim sosyal ve ekonomik problemler sonuçlandırılmadan bu kadar hızlı mutasarrıf değişiklikleri Hınıs'ta keşmekeşe sebebiyet vermiştir denilebilir. Zira bir idarecinin başlattığg çalışmaların sonuçlanmadan görev yerinin değiştirilmesi yapılan icraatların da yarım kalmasını netice verecektir. Özellikle pek çok arşiv kaydında öneminin giderek arttığı belirtilen Hınıs gibi bir sancağın bu kadar hızlı idareci değişikliklerini kaldıramayacağı da ortadadır.

\footnotetext{
${ }^{32}$ BOA. BEO. 2854/213976.

${ }^{33}$ BOA. Irade Dâhiliye (İ. DH) 1455/1325.R-39.

${ }^{34}$ BOA. DH. MKT. 965/79.

${ }^{35}$ BOA. Irade Taltifat (I. TAL). 1325.Ca.15.

${ }^{36}$ BOA. DH. MKT. $1225 / 65$ ve BOA. I. DH. $1466 / 1326$. Ca-32.

${ }^{37}$ BOA. DH. MKT. $2667 / 96$.

${ }^{38}$ BOA. I. DH. 1471/1326.Za-71.

${ }^{39}$ BOA. I. DH. 1472/1326.Z-55, BOA. DH. MKT. 2725/88.
} 
$684^{* \text { TAED }} 54$

Yakup KARATAŞ, Mehmet Kerem KARASU

Ali Ulvi Bey’in Hınıs'ta çok kalmadı̆̆ı, Bayezid Sancağı'nda çeşitli sorunlara yol açan mutasarrıf Rıza Bey ile gerçekleşen becayişleri neticesinde Bayezid'e gittiği anlaşılmıştır. ${ }^{40}$ 1909 yılı ortalarında Hınıs mutasarrıflığına becayişle atanan Rıza Bey’in görevine başlamasını geciktirmesinden dolayı yeni bir tayin gerçekleşmiş ve Kırcaali Kazası Kaymakamı, Mekteb-i Mülkiye mezunlarından ve birinci sınıf intihap-name sahibi Cemal Bey Hınıs'a mutasarrıf olarak atanmıştır. Bu atamada, kendisinin görevde yükselmeye hak kazandığı ifade edilmiştir. ${ }^{41}$ Bu atamanın iradesi 30 Haziran 1909 tarihlidir. ${ }^{42}$ Ancak Cemal Bey'in de görevine başlamış olduğuna ihtimal verilemez. Zira aynı tarihlerde Hınıs'ın yeniden kaza statüsüne indirilmesi gündemde olup bunun gerçekleşmesi hâlinde mutasarrıflık boşa düşecek ve Cemal Bey’in Hınıs'a gitmesine gerek kalmayacaktır.

Beş yıl içinde sekiz farklı mutasarrıfın ataması yapılan Hınıs'ta sırasıyla Tahir Efendi (yaklaşık iki yıl), Ali Nevzad Bey (bir yıl), Ahmed Macid Bey (bir yıl), Halil Şahab Bey (altı ay), Ahmed Rami Bey (bir ay), Ali Ulvi Bey (altı ay), Rıza Bey ve Cemal Bey’ler mülki amir pozisyonunu işgal etmişlerdir. Bu kadar kısa sürede bu derece kısa sürelerle mutasarrıf tayinleri aşağıda da görüleceği üzere Hınıs'ta pek çok girişimin akim kalmasını netice verecektir. Statüsü 3. sınıf sancak olarak tespit edilen Hınıs'a, mutasarrıf maaşlarının düşük olmasından dolayı ancak kaymakamlar mutasarrıf olarak tayin edilebilmişti. Bu durum da Hınıs'ın sadece kaymakamların görevde yükselmeleri için bir basamak olmaktan başka bir anlam ifade etmeyen bir sancak konumuna düşmesine neden olmuştur.

\section{Sancak Teşkilatının Oluşturulması}

Sancağa dönüştürüldükten sonra Hınıs’ta sancak teşkilatının tamamlanması için çeşitli idari ve mülki faaliyetlere girişilmiştir. Bunun için de ilk icraat olarak Pasin ve Kiğı Kazalarının Hınıs'a bağlanması gündeme alınmıştır. Ancak Pasinler ve Kiğı'nın Erzurum'a Hınıs'tan daha yakın oldukları, üstelik Pasinler'in Rusya sınırına bitişik olması ve Kiğı'dan Hınıs'a doğrudan yol bulunmaması gibi sebeplerden dolayı teşkilat bu hâliyle gerçekleşememiştir. Diğer yandan Hınıs Sancağı'na atanacak memurların maaşları için yıllık yaklaşık 100.000 guruş gibi bir ihtiyaç da ortaya çıkmıştır. Bunun dışında Bitlis Vilayeti'ne bağlı olup Fırat Nehri'nin beri tarafındaki bazı köylerle Pasinler'in bazı köylerinin birleştirilip iki kazaya dönüştürülmek

\footnotetext{
${ }^{40}$ BOA. I. DH. 1474/1327.R-30.

${ }^{41}$ BOA. DH. MKT. 2854/84.

${ }^{42}$ BOA. I. DH. 1476/1327.C.54.
} 
suretiyle Hınıs Sancağı'na bağlanması da ayrı bir seçenek olarak ele alınmıştır. ${ }^{43}$ Ancak bu seçeneğin de uygulanamadığı ve Hınıs'a herhangi bir kazanın bağlanamadığı görülecektir. Zira sonraki aylara ait yazışmalarda, yeniden teşkil edilecek iki kazanın masrafları için hazineden karşılık bulunamadığ 1 ifade edilmiştir. ${ }^{44} 1905$ senesinde Sadaret’ten Maliye Nezaretine gönderilen bir yazıda ise söz konusu 100.000 guruşun 1322 / 1906 - 07 senesi bütçesine ilave edilmesi lüzumu bildirilerek gerekenin yapılması istenmiştir. ${ }^{45}$ Ancak buradaki "gerekenin yapılması" kaydının nihai hüküm olmadığı ve "duruma göre hareket edilmesi gerektiği”" anlamını ihtiva ettiği göz önünde bulundurulmalıdır.

Sancak teşkilatı kapsamında Hınıs nüfus memurluğuna Andırın Kazası Nüfus Memuru Abdülkadir Efendi aylık 250 guruş maaşla atanmıştır. Abdülkadir Efendi daha sonra maaşının 500 guruşa çıkarılmasını arz etmiş ve Dâhiliye Nezareti konunun Sadarette sunulduğunu belirterek gelecek cevaba göre işlem yapılacağını bildirmiştir. ${ }^{46}$

Sancağa çevrilmesinden dolayı memur sayısı da artan Hınıs'ta yeni bir hükümet konağ1 yapılması için de faaliyetlere girişilmiştir. Eski konağın hem yetersiz olması hem de temellerinde sarsıntılar meydana gelmesinden dolayı halkın yardımlarına başvurularak yeni bir hükümet konağının inşasına başlanmıştır. Yaklaşık 500 - 600 lira yardım toplanmış ve fevkanisinden dört oda tamamlanmıştır. Kısa sürede bitirilmeye çalışılan konak için yaklaşık 300 liraya daha ihtiyaç olduğu ifade edilmiştir. Bunun 150 lirasını da ileri gelen zenginler ve yerel memurlardan karşılayan idare, kalan 150 lira için de merkezi hazineye başvurmuştur. Şura-yı Devlet ise kalan miktarın 1321 / 1905 - 06 senesi hapishane giderlerinden yapılacak tasarruftan karşılanmasını tavsiye etmiştir. ${ }^{47}$ Erzurum Valisi Mustafa Nazım Paşa, kendi hazırladığ1 altı aylık faaliyet raporunda Hınıs'taki hükümet konağı için "hükümetin şan ve şerefiyle doğru orantılı" ifadesini kullanmıştı. ${ }^{48}$

1905 yılı ortalarında Hınıs'taki polis ve zabıta mevcudunun artırılması ve sancağa bir Jandarma binbaşıSı gönderilmesi için mutasarrıflıkça bir talep gerçekleşmişti. ${ }^{49}$ Ancak 1908

\footnotetext{
${ }^{43}$ BOA. DH. TMIK. S. 52/571, ss 1- 11.

${ }^{44}$ BOA. BEO. 2460/184452.

${ }^{45}$ BOA. BEO. 2513/188475.

${ }^{46}$ BOA. DH. MKT. 891/26.

${ }^{47}$ BOA. DH. MKT. 925/50, s. 1-5.

${ }^{48}$ BOA. Ylldiz Perakende Umum Vilayetler (Y. PRK. UM) 74/106.

${ }^{49}$ BOA. BEO. 2650/198732. Erzurum valiliği Hınıs Mutasarrıflığın bu kolluk gücü talebini doğrudan Padişaha yazması küçük çaplı bir bürokratik kriz çıkarmıştır. Şöyle ki vilayetin doğrudan Saray ile yazışması diğer dairelerde iş ve işlemlerin gecikmesi ile ilişkili bulunmuş ve hangi dairede neden dolayı gecikmeler yaşandığının sebeplerinin araştırılması istenmiştir. BOA. İrade Hususi (I. HUS) 132/1323.C-85.
} 
$\underline{686^{*} \text { TAED }} 54$

Yakup KARATAŞ, Mehmet Kerem KARASU

yılında dahi Hınıs'ın Jandarma sorununun çözülemediği ve mevcut jandarma taburunun hâlâ kaza seviyesinde bulunduğu belirtilmişti. ${ }^{50}$ Hınıs jandarmasının sancak seviyesine çıkarılması yönündeki bu isteğe 1909 yılı ocak ayında cevap verilmişti. Harbiye Nezareti'nden verilen cevapta Hınıs'a herhangi bir kazanın bağlı olmadığı belirtilerek jandarmasının mevcut hâliyle kalmasının uygun olacağı ifade edilmişti. Buna gerekçe olarak da ileride oluşturulacak veya sancağa bağlanacak kazaların jandarma bölüklerinin de ilave edilmesiyle sancak jandarma birliğinin gereken seviyeye ulaşacağ 1 öne sürülmüştü. ${ }^{51}$

Sancak hâline gelen Hınıs'ta belediye tabibi bulunmadığı ve adli ceza işlemlerinde vilayet merkezinden tabip getirtildiği için bir tabip görevlendirilmesi de istenmiştir. Dâhiliye Nezaretinden Erzurum'a bu istekle ilgili olarak gelen cevapta ilk önce bölgede tabip maaşına karşıllk bulunması, daha sonra durumun bildirilmesi istenmiştir. ${ }^{52}$

Hınıs Sancağı'nda defter-i hakani memuru ve başkâtibine verilecek maaşın yıllık toplam 12.768 guruş olduğu kaydedilmişti. Bu giderin ne suretle karşılanacağ Maliye dairesinde görüşülmüş ve adı geçen memurların göreve başlama tarihlerinden itibaren ait oldukları yılın bütçesine ilave edilecek tahsisattan karşılanması uygun bulunmuştu. Defter-i Hakani ve Maliye nezaretlerine konu ile ilgili bilgi verilmişti. ${ }^{53} \mathrm{Bu}$ görevlendirme ilgili başka bir kayıtta tapu iş ve işlemlerini 25 guruş aidatla bir tapu kâtibinin yapa geldiği ve Kürtler ve aşiretler arasındaki münazaa ve çatışmaların da genelde arazi davalarından kaynaklandığı ifade edilerek "erbab-1 iktidar bir defter-i hakani memurunun tayin edilmesi" istenmişti. ${ }^{54} 1906$ y1lı kasım ayında çıkan bir irade ile Erzincan tapu kitabetinde görevli Hasan Tahsin Efendi, Hınıs Defter-i Hakani memuriyetine tayin edilmiştir. Kendisinin güzel hizmetlerinin görüldügü, iktidar ve istikamet sahibi biri olduğu belirtilmişti. ${ }^{55}$

Yukarıda bahsedilen iki kazanın oluşturulamaması ve Polis ve Jandarma masrafları için gerekli tahsisatın temin edilememesi gibi sebeplerden dolay1 1906 y1l gibi erken bir tarihte Hınıs'ın tekrar kaza statüsüne dönüştürülmesi tartışmaları başlamıştır. Bu tartışmaların fitilini ateşleyen husus ise 1318 / 1902 - 03 yıllarında kaza iken nahiye hâline getirilen Tortum'un yeni statüsünün mali ve idari bir fayda sağlamaması olmuştur. Zira kazaya düşürülmesi hâlinde

\footnotetext{
${ }^{50}$ BOA. DH. TMIK. S. 72/30.

${ }^{51}$ BOA. DH. MKT. $2720 / 39$.

${ }^{52}$ BOA. DH. MKT. 1007/43.

${ }^{53}$ BOA. Irade Defter-i Hakani, 1324.Ra.8-6.

${ }^{54}$ BOA. Şura-yı Devlet Evrakı (ŞD) 427/49. Bu kayıtta Defter-i Hakani memuruna 684, başkâtibe ise 380 guruş aidat tahsis edildiği ifade edilmiştir.

${ }_{55}$ BOA. Irade, Defter-i Hakani, 1324.N.24-10.
} 
Hınıs'tan yapılacak tasarruflarla kaza hâline getirilecek Tortum'un memur masraflarının karşılanacağı hesap edilmiştir. Hem Hınıs'ın sancak statüsünden devlet ve millet olarak bir fayda elde edilmediği de vurgulanmıştır. ${ }^{56}$ Öte yandan Dâhiliye Nezareti, 1906 y1lı Aralık ayında henüz kaza teşkilatı tamamlanamayan Hınıs'ta, sancağa dönüştürüldükten sonra bağlı köylerin irtibatında ya da nahiye teşkilatında bir değişiklik olup olmadığı konusunda bilgi istemiştir. ${ }^{57}$ Ancak bu değerlendirmelerden sonra Hınıs'ın sancak statüsünün bir değişiklik yapılmadığı anlaşılmaktadır.

Hınıs'taki haberleşme imkânlarının iyileştirilmesi kapsamında olarak 1907 yılında ahalinin kendi rızaları ile direkleri temin etmesi suretiyle Karaçoban Nahiyesine telgraf hattı götürülmesi gündeme gelmiştir. Nahiyenin meskûn ahalisinin Hristiyan olduğu ve burada fesat hareketlerine müsait bir zeminin de bulunduğu nazara verilerek telgraf hattının çekilmesi durumunda ahalinin iş ve işlemlerinin kolaylaşacağı ve bölgede inzibatın temin edileceği gibi faydalar üzerinde durulmuştur. Hem hattın çekilmesi hem de bir telgraf merkezinin yapılması için direk masraflarının dışında bir defaya mahsus olarak 2.609 Frank 40 Santim ile 20.460 guruşa ihtiyaç duyulduğu ifade edilmiştir. Bunun dışında telgraf merkezinin yıllık maaş vesaire giderleri için de ayrıca 185 Frank ile 14.600 guruşa muhtaç olunduğu belirtilmiştir. Bu masraflara karşılık bulunamaması üzerine bunların bütçeye ilave edilmesi kararlaştırılmıştır. ${ }^{58}$ 1908 yılının ilk aylarında bu hattın ifade edilen masrafları için yeniden bir yazı kaleme alınarak önceki talebin cevapsız kaldığı ifade edilmişti. Bunun üzerine, gerekli ödemelerin bütçeye ilave edilmesi için Sadaretten izin istenmişti..$^{59}$

1908 yılı başlarında Hınıs Liva İdare Meclisince kaleme alınan ve Dâhiliye Nezareti’ne gönderilen bir mazbatada sancağa dönüştürülen Hınıs'ta türlü ilerlemeler kaydedildiği ve esasen buranın ilerleme ve gelişmeye kabiliyeti olduğu da belirtilmiştir. Mazbatada sancak teşkilatının tamamlanması; asayişin sağlanması ve askerî noktalardan zorunluluk olarak öne sürülmüştür. Zira Muş, Malazgirt, Varto ve Bulanık'ta bulunan kimi Hamidiye Alay mensubu kuvvetler askerî muamelelerini Hınıs'tan gerçekleştirmektedirler. Hem bunların ticaret ve alışverişleri de yine ya Erzurum'la ya da Hınıs'la gerçekleşmekte olup uzak olduğu için kendi kazalarına da pek gitmemektedirler. Hatta Malazgirt'in bazı köylerinin ahalisi, Malazgirt uzak olduğu için adli durumlarda bile oraya gitmemekte, Hınıs'taki mahkemelere gelmektedirler. Bunlara benzer

\footnotetext{
${ }^{56}$ BOA. DH. TMIK. S. 64/23, s. 1-17.

${ }^{57}$ BOA. DH. TMIK. S. 65/78.

${ }^{58}$ BOA. DH. MKT. $1206 / 85$.

${ }^{59}$ BOA. SSD. 1159/22.
} 
$688^{*}$ TAED 54

Yakup KARATAŞ, Mehmet Kerem KARASU

başka sorunların da giderilmesi için idari teşkilata dair bir proje geliştirilmiş ve kâğıt üzerinde Kobal Kazası suretinde bir kaza teşkil edilmiştir. Varto ve Bayezid'e bağlı Tutak kazalarıyla Karaçoban, Söylemez ve Halil Çavuş nahiyelerinden yapılacak tasarruflarla yeni kurulacak kazanın masraflarına karşılık tedarik edilmiştir. Bu teklifi desteklemek için yeni oluşturulacak teşkilatın gelir - gider dengesi de kurulmuştur. ${ }^{60}$

1904 yılında sancak hâline getirilen Hınıs 1909 yılı başlarına kadar bu statüsünü muhafaza etmiş ancak mali kaynak yetersizliği ve sancağın sosyo - kültürel ve coğrafi yapısından kaynaklanan bir takım zorluklar, sancak teşkilatının tamamlanmasını zorlaştırmıştır. Durum böyle olunca sancak olarak bir fayda elde edilememiş ve 1909 yılının ilk aylarında Hınıs'ın yeniden kaza derecesine düşürülmesi gündeme gelmiştir. Aynı dönemde nahiye hâlinde iken Tortum'un kazaya dönüştürülmesi de Vilayet idare meclisinin gündemine alınmıştır. ${ }^{61}$ Şura-yı Devlet'in Nisan-1909 tarihli kararına bakılırsa Hınıs'ın tekrar kaza hâline getirilmesi ve Tortum'un da Namervan (Narman)'a katılarak kazaya dönüştürülmesi münasip görülmüştür. ${ }^{62}$ Hınıs'ın sancak teşkilatının tamamlanamamasının kaynak yetersizliğinden dolayı olduğu zaten merkezi hükümetçe de kabul edilmiştir. Sancak teşkilatı tamamlansa bile bir fayda hasıl olmayacağının değerlendirildiği Sadaret mazbatasında, Hınıs'ın yeniden kaza hâline getirilmesi, buradan yapılacak tasarruflarla Tortum'un kazaya yükseltilerek şer'i, mali ve idari personelin maaşlarına karşılık tedarik edilmesi uygun bulunmuştur (28 Haziran 1909). ${ }^{63}$ Hınıs'ın kaza hâline getirilmesine dair resmi işlemlerin aynı yılın Temmuz ayına kadar bitirilmediği tespit edilmiştir. Zira bu hususta Defter-i Hakani Nezareti ile Sadaret arasında bir iletişim eksikliği ortaya çıkmıştır. Bakanlıklar arası bu iletişim sıkıntılarından dolayı Hınıs'ın kaza statüsüne düşürülmesi işlemleri bir ay kadar uzamıştır. ${ }^{64}$ Merkezi hükümet daireleri arasındaki bu tür sorunlar, o dönemde yaşanan 31 Mart İsyanı, Sultan II. Abdülhamid'in hal'i ve Sultan V. Mehmed Reşad'ın cülusu hadiseleri ile birlikte ele alındığında makul görülmelidir. Netice itibariyle Hınıs'ın sancak statüsüne 1909 yılının Haziran - Temmuz aylarında tam anlamıyla son verilmiştir denebilir.

\footnotetext{
${ }^{60}$ BOA. DH. TMIK. S. 72/54.

${ }^{61}$ BOA. DH. MKT. 2729/55.

${ }^{62}$ BOA. Şura-yı Devlet Mülkiye Dairesi (ŞD. MLK.) 1529/18.

${ }^{63}$ BOA. BEO. 3585/268837.

${ }^{64}$ BOA. BEO. 3786/283882. Bu iletişim eksikliğinden dolayı yukarıda mutasarrıflar bahsinde de görüldüğü üzere Hınıs'ın kaza haline getirilmesi kararı Haziran'da alınmış olmasına rağmen Temmuz ayına kadar mutasarrıf atamaları gerçekleşmiştir.
} 


\section{Sonuç}

Osmanlı idaresine alındığ 1 erken tarihlerden itibaren Osmanlı ile İran Devletleri arasında birkaç defa el değiştirdikten sonra nihayetinde Osmanlı idaresinde kalan Hınıs, çeşitli dönemlerde kaza veya sancak olarak idare edilmişti. XIX. yüzyıl başlarına kadar genelde yurtluk - ocaklık sancak şeklinde idare edilen Hınıs Tanzimat'ın idari reformları kapsamında olarak kazaya dönüştürülerek yurtluk - ocaklığı kaldırılmıştı. 1871 tarihli yeni vilayet nizamında da keza Erzurum'a bağlı bir sancak olarak idari ünitedeki yerini almıştır. 1904 yılında çeşitli güvenlik nedenlerine bağlı olarak sancağa dönüştürülen Hınıs'ta ahalinin çeşitli ıslah çalışmaları kapsamında mali yardımları söz konusu olmuştur. Gerek telgraf hattı gerekse hükümet konağının çeşitli masrafları için ahalinin yardımına başvuran bölge idarecileri, sancak teşkilatının tamamlanması için gerekli finansmanı oluşturmada yetersiz kalmışlardır. Diğer taraftan mutasarrıf olarak atanan idarecilerin çok kısa sürelerde görev yerlerinin değiştirilmesi sancağın gelişimi veya teşkilatının tamamlanması noktalarından menfi tesir icra etmiştir. Merkez kaza dışında herhangi yeni bir kaza oluşturulamayıp başka kazalar da Hınıs'a bağlanamayınca Hınıs Sancağı tek kaza ve diğer dört nahiyeden ibaret olarak yönetilmiştir. XX. yüzyılın başlarında yaklaşık beş yıl sancak hâlinde idare edilen Hınıs'ta sosyal ve ekonomik yapının iyi niyetli reformlara çok fazla müsait olmaması nedeniyle Hınıs, tekrar eski statüsüne kavuşturularak kazaya dönüştürülmüştür. Beş yılda sekiz mutasarrıf gören ve 3. sınıftan olduğu için mutasarrıflık maaşının düşük (3.500 Guruş) olduğu Hınıs'a azledilmiş mutasarrıflar rağbet etmediğinden genelde terfie hak kazanan 1. sınıf kaymakamlar idareci olarak atanmıştır. Mutasarrıf olarak ilk idari tecrübelerini Hınıs'ta yaşayan bu kaymakamların oldukça kısa olan görev süreleri de birlikte düşünülürse bölgede kalıcı eser bırakmaktan uzak olacakları anlaşılır. Bu açıdan bakınca Hınıs adeta kaymakamların terfi etmeleri için açılmış bir sancak statüsünden başka bir görünüm arz etmemiştir.

\section{Kaynaklar}

\section{a) Araştırma Eserleri}

Aydın, D. (1998). Erzurum Beylerbeyliği ve Teşkilat-Kuruluş ve Genişleme Devri (1535-1566), Ankara: TTK Yayınları.

Başar, F. (1997). Osmanlı Eyalet Tevcihatı (1717-1730), Ankara: TTK Yayınları.

Binbaşı M. Nasrullah, Kolağası M. Rüşdü ve Mülazım M. Eşref (2003). Osmanlı Atlası (XX. Yüzyıl Başları), (Yay. Haz. Rahmi Tekin, Yaşar Baş), İstanbul: OSAV Yayınları. 
$690^{* \text { TAED }} 54$

Yakup KARATAŞ, Mehmet Kerem KARASU

Cuinet, V. (1892). La Turquie d'Asie, Geographie, Administrative, Statistique, Descriptive et Raisonnee de Chaque Province de L'asie Mineure, Paris, c.I.

Günay, S. (1988). "Hamidiye Hafif Süvari Alayları ve Erzurum”, Türk Dünyası Araştırmaları Dergisi, Nisan, S. 53, s. 81-85.

Hınıs Livası Mufassal Tahrir Defteri (2000). Yay. Haz. Ahmet Özkılınç, Ali Coşkun, Abdullah Sivridağ, Murat Yüzbaşığlu, Ankara: Devlet Arşivleri Genel Müdürlüğü Yayınları.

Karaca A. (1993). Anadolu Islahatı ve Ahmed Şakir Paşa (1838-1899), İstanbul: Eren Yayınları.

Karataş, Y. (2010). Sultan II. Abdülhamid Dönemi'nde Erzurum (Sosyal, Ekonomik, İdarî ve Demografik Yapı), (Yayımlanmamış Doktora Tezi) Atatürk Üniversitesi Sosyal Bilimler Enstitüsü, Erzurum.

Karataş, Y. (2014). Bayezid Sancağı ve İdarecileri (1700-1914) İstanbul: Kitabevi.

Kılıç, O. (1997). 18. Yüzyılın İlk Yarısında Osmanlı Devleti'nin İdari Taksimatı-Eyalet ve Sancak Tevcihatı, Elazı̆̆.

Kılıç, O. "Ocaklık Sancakların Osmanlı Hukukunda ve İdarî Tatbikattaki Yeri”, http://web.firat.edu.tr/sosyalbil/dergi/arsiv/cilt11/sayi1/257-274.pdf.

Kunt, İ. Metin (1978). Sancaktan Eyalete (1550-1650 Arasında Osmanlı Ümerast ve İ İdaresi), İstanbul: Boğaziçi Üni. Yayınları

Salname-i Vilayet-i Erzurum (SVE) 1315 / 1900, Erzurum

Şemseddin Sami (1308 / 1893). Kâmûs-ül A 'lâm C. 3, İstanbul: Mihran Matbaası

b) Osmanlı Arşivi Belgeleri

Başbakanlık Osmanlı Arşivi Babıali Evrak Odası Belgeleri (BOA. BEO), Dosya Numarası: 2294, Gömlek Numaras1: 172019, 3057/229235, 3438/257787, 2460/184452, 2513/188475, 2650/198732, 3585/268837, 3786/283882

BOA, Dâhiliye Mektubi Kalemi Evrakı (BOA. DH. MKT.) 2482/94. 891/26, 2624/97, 1104/13, 1128/75, 965/79, 1225/65, 2667/96, 2854/84, 2725/88, 891/26, 925/50, 2720/39, $1007 / 43,1206 / 85,2729 / 55$,

BOA. Dâhiliye Tesri-i Muamelat ve Islahat Komisyonu, Islahat Kısmı (BOA. DH. TMIK. S) $72,30,52 / 571,72 / 30,64 / 23,65 / 78,72 / 54,72 / 30,2854 / 213976$.

BOA. Irade Dâhiliye (i. DH) 1455/1325.R-39, 1466/1326.Ca-32, 1471/1326.Za-71, 1472/1326.Z-55, 1474/1327.R-30, 1476/1327.C-54.

BOA. İrade Defter-i Hakani, 1324.Ra.8-6, 1324.N.24-10.

BOA. İrade Hususi (İ. HUS) 132/1323.C-85.

BOA. Irade Taltifat (I. TAL). 1325.Ca.15. 
BOA. Şura-yı Devlet Evrakı (ŞD) 427/49, 1159/22.

BOA. Şura-yı Devlet Mülkiye Dairesi (ŞD. MLK.) 1529/18.

BOA. Yuldı Mütenevvi Maruzat (Y. MTV.), 255/221.

BOA. Yıldı, Perakende Askeri Evrakı (Y. PRK. ASK) 213/33.

BOA. Yıldı Perakende Başkitabet Evrakı (Y. PRK. BŞK), 71/97.

BOA. Yuldiz Perakende Umum Vilayetler (Y. PRK. UM) 74/106.

BOA. Zabtiyye Nezareti Belgeleri (ZB), 318/101. 